\title{
Job Satisfaction and Occupational Stress on Medical Representatives in Trichy and Tanjore Districts of Tamil Nadu
}

\author{
Thamilvanan G, Thavasumani S
}

\begin{abstract}
Key objective of the study is to analyse interrelation among Job satisfaction and Occupational Stress of Medical representatives in Trichy and Tanjore districts of Tamilnadu. The variables of the analysed by this study are Dependent variable- Job Satisfaction, Independent variable - Occupational Stress and Attributable variable -Year of Experience and co-workers. Medical representatives play a major role in profits and awareness for the concern industry in a short duration to achieve a target of corporate nevertheless to grieved with more physical and mental stress. Occupational stress index was given to assess the stress levels and job satisfaction scale were given to assess the satisfaction level. The correlation analysis revealed the important negative correlation amongst job satisfaction and occupational stress. This indicates that occupational stress basically dependent on job satisfaction. Henceforth, this study proposes to frame the parameters of human resource strategy by the organisation or industry on job satisfaction of medical representatives will help to reduce their occupational stress.
\end{abstract}

Index Terms: job satisfaction, Medical Representative, Occupational Stress, Stress.

\section{INTRODUCTION}

Pharmaceutical Companies are publicizing their product predominantly with the direct communication with medical professionals by skilled competent medical representatives to enhance the sales rate of their product. To advertising their distinctive pharmaceutical items, organizations require an ever-increasing number of talented skilled medical representatives to grow great compatibility with Medical experts (Doctors). More over representatives ought to have more information about the products, Unique Selling Proposition (USP), to persuade specialists and force the interest on their products.

In this context doctors are the core clients and the real push is given to find and maintain those clients until they have got interest on their products thus organizations additionally give fundamental attention in structure and holding these clients. The medical representatives working in this environment are pushed to attain the stress condition by Pharmaceutical and Biomedical industrial sectors. Representatives encountering the stress by various factors like high targets, type of work, high workload, tight deadlines, long working hours, reduced job satisfaction, force to perform and so forth.

Revised Manuscript Received on July 22, 2019

Thamilvann G, Department of Education, Periyar Maniammai Institute of Science and Technology (Deemed to be University, Thanjavur, India.

Thavasumani S, Department of Education, Periyar Maniammai Institute of Science and Technology (Deemed to be University, Thanjavur, India.
Stress prompted weakness, crabbiness, poor correspondence, and quality issues/mistakes, because of this they may feel disappointed or "wore out" when they are having issues with administrators or clients. Individuals from the industries are articulating the various stressors like Excessive workload, conflicts of role, interpersonal disputes with clients and absence of advancement or improvements shown by clients (Shinn et al, 1984). The practices of these kind of stressors results in terrible execution. Thus, it was felt appropriate to think about the connection among occupational stress and job performance of Medical Representatives of Trichy and Tanjore Districts of the Tamilnadu.

\section{A. Stress}

Bruno (1991) characterizes stress as the mileage rate on a living being. Selye (1976) a doctor from Canada, was an initial pilgrim in effects of stress over well-being. Selye characterized stress is entirety of every single nonspecific change brought about by purpose or impairment. From his medicinal point of view, Selye proposed the body reacts on mental fluctuations relevant with "fight or flight" disorder.

\section{B. Occupational stress}

Occupational stress is damaging physical and mental reactions that ensue when the work demands does not match with worker's abilities, requirements or needs of the employee. Stress at working environment can result in bad health and may even causes accidental injury. Ideally Occupational stress is confused with challenge, but not the same. Challenge strengthens us both physically and psychologically, encouraging us to learn additional abilities and strengthen our occupations. We feel the fulfilment and satisfied when the challenge is achieved (U.S. NIOSH, 1999). Occupational stress as "a state of mental and physical effort realized because of distressing occasions or disappointing components or general practices of the workplace" defined by Okebukola and jedgede (1989).

Nearly everyone agrees that Occupational stress results from the worker's interaction and working circumstances However, views vary on the significance of employee features versus working circumstances as the main cause of occupational stress. These distinct points of view are crucial because they propose distinct methods to avoid stress at job. 


\section{Job satisfaction}

In 1935, understanding of job satisfaction chosen cash through Hoppock's spreading of a monograph. The monograph described job satisfaction as "any inclusion of mental, physiological, and ecological conditions that honestly leads an individual to state ' I remain pleased with my work. ' Movements of an individual towards the work is job satisfaction. Inspirational mentality with their the job is considered as job satisfaction, while adverse frames of mind towards occupation are identical to work dissatisfaction. Employment satisfaction has been defined differently over and over again.

\section{Industry Profile}

The last fourty years of Indian pharmaceutical industries has reached sudden growth and transformation. The survey states that in 1947 the turnover is Rs. 10 crore, Where as in 2004, US $\$ 5.5$ billion were reached with the annual progress rate of $17 \%$. As per Pharmaceutical Department, Ministry of Chemicals and Fertilizers, pharmaceutical industry's of India total turnover between 2008 and September 2009 was US\$ 21.04 billion. As stated by the Brand India Equity Foundation, the Indian pharmaceutical industry is likely to evolve at a compound annual growth rate (CAGR) of 14-17 percent in mid-2012-16. There were 4,655 pharmaceutical assembly plants throughout India in 2013, using more than 345 thousand experts. The adaptable agreements of the 1970 Patent Act and the Government of India's supporting policies played an instrumental part in the growth and development of this sector. India is currently one of the world's top five pharmaceutical developing sectors.

\section{E. The Development of Indian Drug and Pharmaceutical Industry}

The history of the evolution of Indian Pharmaceutical Industry can be divided into four primary epochs. The first epoch was between 1850 and 1945. The second epoch stretches from 1945 until the late 1970s. The third epoch of development is from the early 1980s to the early 1990s, and the fourth epoch stretches from the early 1990s to the present. 1. To determine the occupational stress level of medical representatives

2. To find the job level Satisfaction of medical representatives 3. To determine the interrelation between occupational stress and job satisfaction of medical representatives.

\section{HYPOTHESIS}

There is no significant corelation with Occupational Stress and Job Satisfaction among Medical representatives.

\section{RESEARCH METHODOLOGY}

There is no significant corelation with Occupational Stress and Job Satisfaction among Medical representatives.

\section{A. Research Methodology}

Survey method were used for this study
150 Medical representatives were selected in Trichy and Tanjore Districts of Tamil Nadu.

\section{Sampling of the study}

The sampling technique was applied in the present study is convenience sampling. Convenience Sampling refers to Availability, Convenient time and place of Medical representatives to cooperate to respond and the final sample to be included in this study is 150 pharmaceutical sales representatives in Trichy and Tanjore districts of Tamil Nadu.

\section{Tools of the study}

The following two tools were used for evaluate the considered variable

1. Paul E Spector (1994) standardized job satisfaction and it contains 36 items to be answered on a six-point scale.

2. Occupational stress explained by A K Srinivastava and A P Singh (1984) and the scale comprises of 12 variables having 46.

\section{E. Analysis of statistical data}

The techniques were used to analyse the data according to the goals of the previously specified research.

I. Mean

II. Standard deviation

III. T test

IV. Correlation Analysis

\section{RESULTS AND DISCUSSION}

Descriptive Statistics for Stress

\begin{tabular}{|l|l|}
\hline \multicolumn{2}{|c|}{ Occupational Stress } \\
\hline \multicolumn{1}{|c|}{ Parameter } & \multicolumn{1}{c|}{ Result } \\
\hline Mean & 83 \\
\hline Standard Error & 1.77 \\
\hline Median & 83 \\
\hline Mode & 46 \\
\hline Standard Deviation & 21.72 \\
\hline Sample Variance & 471.81 \\
\hline Range & 74 \\
\hline Minimum & 46 \\
\hline Maximum & 120 \\
\hline Sum & 12450 \\
\hline Count & 150 \\
\hline
\end{tabular}

Table 1: Descriptive Statistics for Occupational Stress Among Medical representatives studied, the mean stress recorded was 83 with the maximum recorded at 120 and the minimum recorded at 46 with a standard deviation of 21.72 
Descriptive Statistics for Job Satisfaction

\begin{tabular}{|l|l|}
\hline \multicolumn{2}{|c|}{ Job Satisfaction } \\
\hline Parameter & Result \\
\hline Mean & 146.19 \\
\hline Standard Error & 1.77 \\
\hline Median & 147 \\
\hline Mode & 150 \\
\hline Standard Deviation & 21.71 \\
\hline Sample Variance & 471.49 \\
\hline Range & 87 \\
\hline Minimum & 107 \\
\hline Maximum & 194 \\
\hline Sum & 21929 \\
\hline Count & 150 \\
\hline
\end{tabular}

Table 2: Descriptive Statistics for Job Satisfaction

Among Medical representatives studied, the mean job satisfaction recorded was 146.19 with the maximum recorded at 194 and the minimum recorded at 107 with a standard deviation of 21.71

\section{Hypothesis}

There is no important connection between medical representatives and Occupational Stress and Job Satisfaction.

Data Review:

\begin{tabular}{|l|c|c|}
\hline \multicolumn{1}{|c|}{ Group } & Stress & Job Satisfaction \\
\hline Mean & 152.06 & 142.98 \\
\hline SD & 18.28 & 6.28 \\
\hline SEM & 1.49 & 0.51 \\
\hline N & 150 & 150 \\
\hline
\end{tabular}

Table 5: Result for Hypothesis

\section{' $t$ ' test result}

$P$ value: If two-tailed $P$ value is $<0.0001$, highest statistical significance is present with the variables

\section{Confidence interval:}

The mean difference of Occupational Stress and Job Satisfaction is 9.08

95\% confidence interval of this difference: From 5.97 to 12.19

Intermediate values used in calculations:

$\mathrm{t}=5.7532$

$\mathrm{df}=298$

Standard error of difference $=1.578$

Table 6: Correlation Result

The correlation between Stress and Job Satisfaction is as follows:

\begin{tabular}{|c|c|c|}
\hline Parameter & Stress & job satisfaction \\
\hline Stress & 1 & \\
\hline job satisfaction & -0.86774 & 1 \\
\hline
\end{tabular}

In the study conducted among Medical representatives of pharmaceutical companies, it is found that occupational stress is negatively correlated to the job satisfaction of these employees to a large extent.

\section{FINDINGS}

In general the more percentage of medical representatives reveals that the occupational stress in their employment is high. As far as connection, abnormal state of occupational stress may prompt lower work fulfilment in the work environment. This investigation presents three remarkable results: hypothetical commitment, strength of research methodology, and realistic commitment.

As far as hypothetical commitment, the consequences of this investigation affirm that occupational stress as a significant determinant of occupation fulfillment in the examined industries This outcome is predictable with the investigations by Antoniou et al. (2003), Quoidah and Hansenne (2009), Snelgrove (1998), and Starcciarini et al. (2004).

The strength of research methodology is, the survey questions are framed only from the literature available on occupational stress, the painstaking interview had surpassed a minimum standard of legitimacy and reliability analysis. Consequently, it could prompt the creation of exact and solid findings. As far as down to earth commitments, the discoveries of this investigation can be utilized as a rule by the administration to beat occupational pressure issues in pharmaceutical associations. The target might be accomplished if the board thinks about the accompanying proposals: right off the bat, update the substance and preparing technique. For instance, the substance of preparing projects need to stress more on delicate abilities, particularly passionate insight. Uncovering workers with the idea and standards of passionate knowledge will build their abilities in utilizing, directing and overseeing feelings to control physical and mental pressure indications in performing work. The essential of trainings will be effectively actualized whether workers are prepared utilizing legitimate contextual analyses and pretend systems.

Furthermore, inspire employee assistance program through specialized consultants or internal counselling and guidance unit. For instance, including workers in cooperation arranging and organization will assist them with increasing positive socialization, improve vocation and increment psychosocial prosperity. Third, advance work-life balance activities. For instance, to lessen the representative word related pressure, for example, compose organization trips for the worker to loosen up their psyches and bodies, just as start physical wellness and game recreations. At last, energize worker help program through expert specialists or inward directing and direction unit. For instance, the ability of directors to give good and material help to representatives who have encountered social and money related issues may assist them with decreasing every day work issues and increment their fulfilment in playing out the activity. On the off chance that associations intensely consider these recommendations this may emphatically propel their representatives to perform employment targets adequately. 


\section{CONCLUSION}

The correlation assessment shows that employee satisfaction is negatively correlated and substantially linked with the enhanced rate of medical representatives ' occupational pressure. It is very crucial that the top management of pharmaceutical companies understand the requirements of their medial representatives and its availabiltiy. Constant evaluation programs and recognition should be provided to reinstate and motivate the medical reps. To improve the fulfillment of workers ' employment and lives, compensation should be provided with equitable incentives. These incentives would consider the financial benefits, motivational rewards, main decision-making impact, career path

advertising, accessibility of career planning tools and equity. The variables of satisfaction with workload and professional support, Pharmaceutical companies ' top management should allocate appropriate time for workload and should provide supervisor training to coach and oversee their subordinate and setup course for team building.

\section{REFERENCES}

1. Ahsan, N, “A study og job stress on job satisfaction among university staff in malaysia empirical study", European journal of social science, volume 8, Number 1, 2009.

2. Akthak, G, "An Overview on Indian pharmaceutical Industry", IORS journal humanities and Social science, 2015.

3. Alireza, K. A., "Sress and job satisfaction among Air Force Military Pilots", Journal of Social Science, 159-163.

4. Anbhuti Monga, V. M., "Organizational culture,Stress and Commitment:A study of Pharmaceutical managers in Himachal pradesh", Open Access Journal 5, 2013.

5. Antoniou, A.S.G., Davidson, M.J., \& Cooper, C.L., "Occupational stress, job satisfaction and health state in male and female junior hospital doctors in Greece", Journal of Managerial Psychology, 18(6),2003, pp. 592- 621

6. Arafat, S, "A study on Job Statisfaction among Medical Representatives in Bangaladesh. Australion Journal of Business and Management, 05, No.2, 2015.

7. Banks, M.H., Clegg, C.W., Jackson, P.R., Kemp, N.J., Stafford, E.M. and Wall, T.D., "The use of the General Health Questionnaire as an indicator of mental health in occupational studies", Journal of Occupational Psychology, 53, 1980, pp. 187-194

8. Barling, J, "Employment, Stress, and Family Functioning", New York: Wiley, 1990.

9. Baruch, Y., and Hind, P, "Perpetual motion in organisations: Effective management and the impact of the new psychological contracts on "Survivor Syndrome", European Journal of Work and Organisational Psychology, 8 (2), 1999, pp.295-306.

10. Bass, Barnard M, and Barret, Gerald V. Man, Work and Organisations: Introduction to Industrial and Organisational Psychology, Allyn and Bacon, Boston, 1972.

11. Beaton, R., Murphy, S., and Pike, K, "Symptoms of stress in male and female firefighters/paramedics. In Proceedings of the National Institute of Occupational Safety and Health Conference - Stress in the 90s: A Changing Workforce in a Changing Workplace", Washington: NIOSH, 1992.

12. Beck, A, "Cognitive Approaches to Stress", Principles and Practices of Stress Management, 1984, 91-110. New York: Guilford Press

13. Beer, M., Eisenstat, R. A., and Spector, B, "The Critical Path for Corporate Renewal”, Harvard: Harvard Business School Press, 1990.

14. Beer, M., Spector, B., Lawrence, P., Mills, D.Q., and Walton, E, Human Resource Management: A General Manager's Perspective Text and cases. New York The Free Press, 1985.

15. Belous, R, "The shift towards contingent workers", Monthly Labour Review, 112(3), 1998, pp.7-12.

16. Berliner, W and M C Larney, Managemnet Practice and Training, Homewood. 1974.
17. Berridge, J., Cooper, C.L., and Highley-Marchington, C, Employee assistance programs and workplace counselling. New York: Wiley, 1997

18. Beugre, C. D, "Perceived Injustice and Workplace Aggression: The Role of Cognition - Philadelphia”, Kent State University, 1999.

19. Biersner, R., "Developing an occupational stress standard: Rule-making pitfalls. In L. Murphy and J Hurrell and S. Sauter and G. Keita (Eds.). Job Stress Interventions", Washington, DC: American Psychological Association, 1995.

20. Black, James, M., Positive Disciplien, American Management Association, 1970.

21. Breznitz, S. and Goldberger, L., "Stress research at a crossroads. In L. Goldbergerand S. Breznitz, (Eds.). Handbook of stress: Theoretical and clinical aspects, (2nd Ed), (pp.3-6). New York: The Free Press, 1993.

22. Brief, A.P., Burke, M.J., George, J.M., Robinson, B.S., and Webster, J., "Should negative affectivity remain an unmeasured variable in the study of job stress?", Journal of Applied Psychology, 73, 1982, pp. 193-199.

23. British Insitute of Management, Job Evaluation: A Practical Guide for Managers, 1970 .

24. Brown, G.W, "Life event and affective disorder: Replications", Psychosomatic Medicine, 55, 1993, 248-259.

25. Browne, J.H, "Benchmarking HRM practices in health work organizations", American Business Review, 18 (2), 2000, pp. 50-61.

26. Bruce, W.M, "Problem Employee Management: Proactive Strategies for Human Resource Managers", New York: Quorum Books, 1990.

27. Bull, H, "Stress - fact or fiction: The assessment and management of Workers' Compensation claims for stress: A Commonwealth perspective" Proceedings of the National Institute of Occupational Safety and Health Conference - Stress in the 90s: A Changing Workforce in a Changing Workplace. Washington: NIOSH, 1996.

28. Cameron, K., and Smart, J, "Maintaining effectiveness amid downsizing and decline in institutions of higher education", Research in Higher Education, 39, 1998, pp. 65-86.

29. Cartwright, S., Cooper, C.L., and Murphy, L, Diagnosing a healthy organisation: A proactive approach to stress in the workplace. In L Murphy and J. Hurrell and S. Sauter and G Keita (Eds.), Job Stress Interventions. Washington, DC: American Psychological Association, 1995.

30. Cascio, W.F, Wither industrial and organisational psychology in a changing world? American Psychologist, 50, 1995, pp. 928-939.

31. Cavanaugh, M.A., and Roehling, M.V., and Boswell, W.R., and Boudreau, J.W, An Investigation of 'Challenge' and 'Hinderance' Related Stress Among Managers. Ithaca: School of Industrial and Labour Relations, 1999. 